\title{
Alkaline phosphatase activities and the relationship to inorganic phosphate in the Pomeranian Bight (southern Baltic Sea)
}

\author{
Monika Nausch* \\ Institut für Ostseeforschung, Seestraße 15, D-18119 Rostock-Warnemünde, Germany
}

\begin{abstract}
Alkaline phosphatase activities (APA) were estimated along salinity gradients between the mouth of the Szwina and the open Pomeranian Bight (Baltic Sea) and compared to the distribution of phytoplankton biomass (chlorophyll $a, c h l a)$, bacterial counts, and inorganic phosphate. APA and chl a showed a linear decrease along the gradients and correlated with each other. For the interaction between APA and phosphate, a threshold concentration of $1 \mu \mathrm{M}$ phosphate was found. Below this threshold, 2 mechanisms characterize the relationship between APA and phosphate: (1) an increase in specific APA of algal cells at phosphate concentrations of $<0.2 \mu \mathrm{M}$ and (2) a linear correlation between APA and the phytoplankton biomass at phosphate concentrations of between 0.2 and $1 \mu \mathrm{M}$. The inverse relation between APA and phosphate was also shown in mesocosm experiments.
\end{abstract}

KEY WORDS: Alkaline phosphatase - Inorganic phosphate P Phosphate regeneration · Salinity gradients - Phytoplankton

\section{INTRODUCTION}

Inorganic nutrients show a pronounced seasonality in the eutrophic layer of the Baltic Sea. Inorganic nutrients start to decrease in spring and reach low levels from June to August due to the development of phytoplankton. The concentrations of inorganic nutrients are frequently at the detection limit (Nausch et al. 1998). At that time, the entire phosphate pool consists almost exclusively of organically bound phosphorus (Nehring et al. 1995). Relatively constant values for the phytoplankton biomass and for primary production from May to August (HELCOM 1996) require a continuous supply of nutrients. Phosphate for primary production can be supplied by remineralization of organic phosphorous compounds, by release of phosphate by zooplankton (Moegenburg \& Vanni 1991, Postel et al. 1992, Gulati et al. 1995, Vadstein et al. 1995, Hantke et al. 1996) and phagotrophic protozoa (Nagata \& Kirchman 1992), and by external input from land.

\footnotetext{
•E-mail: monika.nausch@io-warnemuende.de
}

The river Oder, with an annual water outflow of about $18 \mathrm{~km}^{3}$, is the largest external source of nutrients entering the Pomeranian Bight $(40000$ to $80000 \mathrm{t} \mathrm{N}$ and 5000 to 8000 t $P ~_{\mathrm{yr}^{-1}}$; Pastuszak et al. 1996). I anticipated that the input of inorganic nutrients into the Pomeranian Bight stimulates the phytoplankton production in this area. However, in the growth period, the inorganic nutrients were taken up by phytoplankton that was already present in the Szczecin Lagoon. Water masses entering the Pomeranian Bight have low concentrations of inorganic nutrients (Nausch et al. 1998), high primary production of about $1.7 \mathrm{~g} \mathrm{C} \mathrm{m}^{-2} \mathrm{~d}^{-1}$ (Jost \& Pollehne 1998) and, consequently, a high load of particulate organic material. The seasonality of nutrients and phytoplankton is qualitatively similar to that observed in the open Baltic Sea, but is of a higher quantitative level. Since the input of inorganic nutrients from external sources, as well as from sandy oxic sediments, is low in summer months (Frankowski \& Bolałek 1997, Kerstan \& Nausch 1998), the supply of phosphate for algal and bacterial growth must be provided by internal cycling within the pelagic zone. 
Regeneration of phosphate from organic compounds is a result of hydrolytic degradation by free and cellsurface bound enzymes of phytoplankton and bacteria: alkaline phosphatase and 5'nucleotidase (Tamminen 1989, Ammerman \& Azam 1991, Chróst 1991). Because stimulation of alkaline phosphatase activity (APA) is more sensitive to low phosphate concentrations than is 5 'nucleotidase stimulation, APA was used as an indicator for phosphate limitation (Paasche \& Erga 1988, Ammerman 1991, Chróst 1991, Lapointe 1995).

I investigated the role of alkaline phosphatase in the pelagic nutrient cycle of the Pomeranian Bight and related it to inorganic phosphorus in summer and autumn, taking into account mixing of riverine water with marine water. The distribution pattern of different parameters and activities along the salinity gradient were not only caused by a simple dilution. Especially in the growth season, a lot of interactions take place there which regulate the function of plankton community (Pollehne et al. 1995, Jost \& Pollehne 1998). The relationship between APA and phosphate concentrations is an example of this interaction.

\section{INVESTIGATION AREA AND METHODS}

Before water from the river Oder enters into the Pomeranian Bight it must pass through the Szczecin
Lagoon. The Szczecin Lagoon and the Pomeranian Bight are connected via the rivers Peene and Szwina (Fig. 1). In the lagoon, river water (fresh water) is mixed with water from the bight (about 7 PSU, practical salinity units), resulting in a salinity range between 0.5 and 2 PSU. Depending on the hydrographical and hydrological conditions, water enters the Pomeranian Bight in a pulse-like manner and in plumes of different sizes (von Bodungen et al. 1995), which are mixed with bight water within 2 or $3 \mathrm{~d}$. We used the salinity as an indicator of different water bodies and their mixing. The distance from the mouth of the Szwina cannot be used as an indicator for dilution, because, depending on the size of the plume, wind speed and wind direction, the water masses were mixed at different time scales and at different distances and directions from the mouth of the Szwina.

Mixing processes were investigated 4 times between the autumn of 1993 and the autumn of 1995. Input events were followed in drift experiments from the mouth of the Szwina to the open bight in September/October 1993, June/July 1994 and June/July 1995 by marking the water body with a drifting buoy. Water samples were taken at depths of 1,5-6 and $8-10 \mathrm{~m}$ with a rosette sampler combined with a CTD (conductivity, temperature and density) and chlorophyll fluorescence probe. In September/October 1995, sampling of surface water along a horizon-

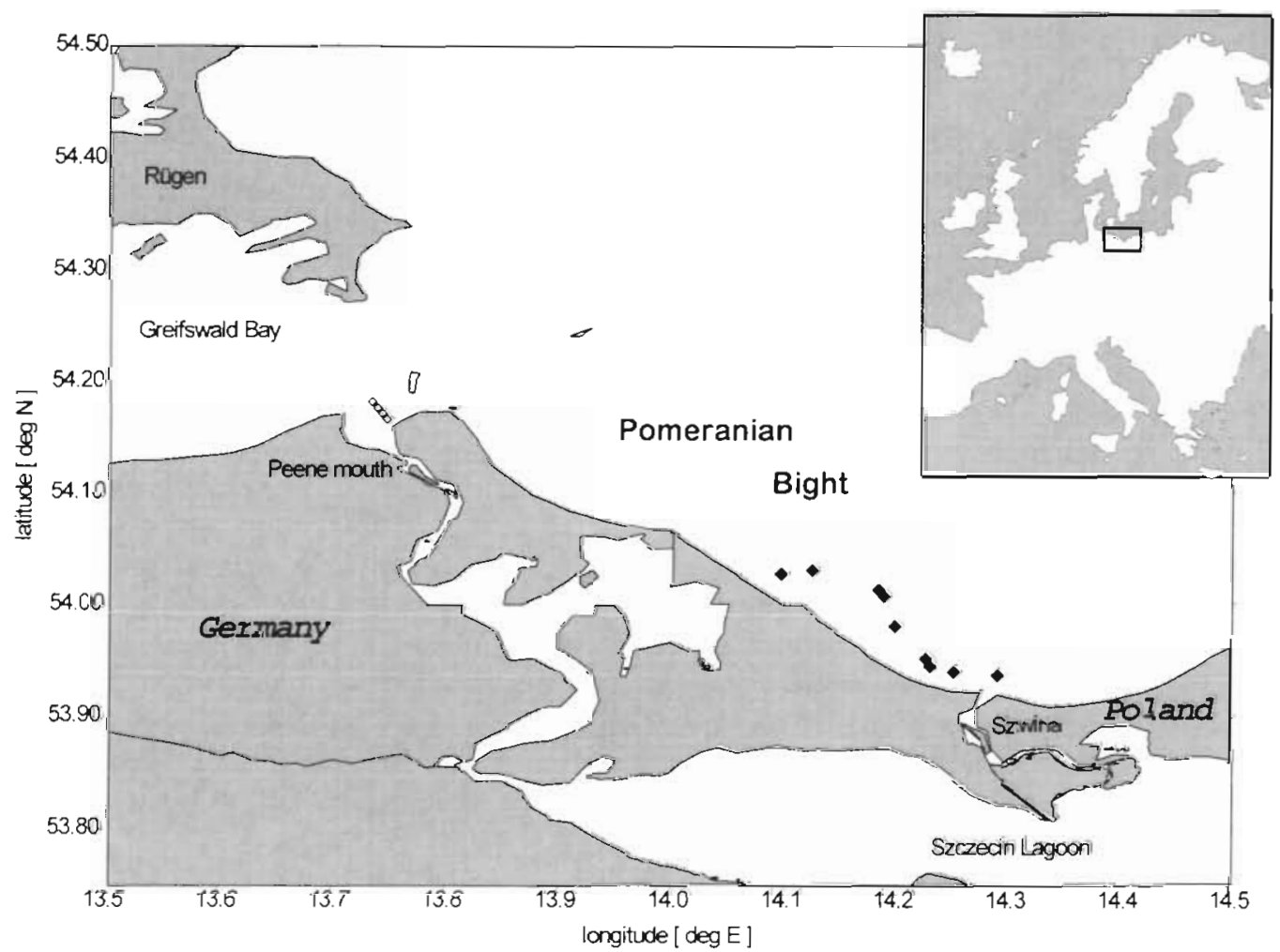

Fig. 1. The Pomeranian Bight in the southern Baltic Sea with sampling stations during drift experiments $(\bullet)$ and the transects $(0)$ 
tal salinity gradient was performed near the mouth of the Peene (Fig. 1). Samples were processed immediately after sampling.

Inorganic phosphate was analysed using standard colorimetric methods according to Rohde \& Nehring (1979) and Grasshoff et al. (1983).

Chlorophyll a (chl a) was determined fluorometrically (exitation $450 \mathrm{~nm}$, emission $670 \mathrm{~nm}$ ) after filtration on GF/F filters and extraction in $90 \%$ acetone (UNESCO 1994). Conversion of chl a values to phytoplankton carbon was undertaken using a carbon: chlorophyll ratio of 50 (Pollehne et al. 1995).

Water samples for bacterial counts were preserved with $0.5 \%$ formaldehyde, filtered onto $0.2 \mu \mathrm{m}$ black Nucleopore filters, stained with a 4',6-diaminidino-2phenylindole (DAPI) solution (Coleman 1980, Kepner \& Pratt 1994) for $5 \mathrm{~min}$ and mounted in immersion oil. Cells were counted and sized with an epifluorescence microscope (Zeiss) and a semiautomatic image analysis system (Photometrics). Conversion to bacterial carbon was calculated according to Fry (1988) using a conversion factor of $308 \mathrm{fg}_{\mathrm{\mu m}^{-3}}$.

APA were measured using the fluorescent substrate analogous 4-methylumbelliferyl-phosphate (MUFphosphate) (Hoppe 1983, 1993, Ammerman 1991, Chróst 1991). We measured the maximum hydrolysis rates ( $\left.V_{\max }\right)$ at saturation concentrations of the artificial substrates and the in situ hydrolysis rates or times at low substrate concentrations. For the estimation of $V_{\max }$ substrates were added at saturation concentrations of $250 \mu \mathrm{M}$. Tests showed that this concentration was reached at $100 \mu \mathrm{M}$ MUF-phosphate. In situ hydrolysis times of natural substrates were estimated at trace amounts of $0.1 \mu \mathrm{M}$. Fluorescence readings were carried out using a spectrofluorometer (Hitachi, F-2000) at $364 \mathrm{~nm}$ exitation and $445 \mathrm{~nm}$ emission. Calibration was performed with standard solutions of 4-methylumbelliferone (MUF) in the range 0.03 to $1 \mu \mathrm{M}$. Tests were carried out in triplicate in the dark and at in situ temperatures. Negative controls were performed using boiled surface water.

Mesocosm experiments were performed from January 18 to February 23, 1996. Polyethylene tanks were filled with 1000 l surface water collected in front of the mouth of the Szwina (4.2 PSU) and from the Arkona Basin (7.7 PSU). The tanks were illuminated permanently with artifical light $(500 \mathrm{~W}$ halogen lamp, light intensity above the surface $200 \mu \mathrm{E} \mathrm{m} \mathrm{m}^{-2}$ $\mathrm{s}^{-1}$ ). Temperatures in the tanks ranged from 0 to $3^{\circ} \mathrm{C}$, which are similar to the in situ water temperatures. Nutrient concentrations, chl $a$ and APA were measured over a period of $36 \mathrm{~d}$ at intervals of $24 \mathrm{~h}$ for the first $8 \mathrm{~d}$, and at intervals of $2 \mathrm{~d}$ for the remainder of the time.

\section{RESULTS}

Inorganic phosphate concentrations along the salinity gradient during the different experiments in summer and autumn are shown in Fig. 2. Summer phosphate concentrations ranged between 0 and $0.2 \mu \mathrm{M}$; autumn phosphate concentrations were generally higher $(0.28$ to $2.66 \mu \mathrm{M})$. In 1993, an input event could be detected with extremely high concentrations near the mouth of the Szwina and a subsequent linear decrease was detected during the dilution processes.

Along all salinity gradients, APA decreased significantly with increasing salinity (summer data pooled from June/July 1994 and 1995: $\mathrm{r}=-0.46, \mathrm{n}=64, \mathrm{p}=$ 0.01 ; autumn data pooled from September/October 1993 and 1995: $\mathrm{r}=-0.81, \mathrm{n}=50, \mathrm{p}=0.01$ ). The APA $V_{\max }$ was 5 to 30 times higher in summer than in autumn, but there were larger variations in summer (Fig. 3). Higher APA activities were measured in seasons when the phosphate level was close to the detection limit (summer), whereas lower APA were found in autumn when sufficient phosphate was present (Fig. 2).

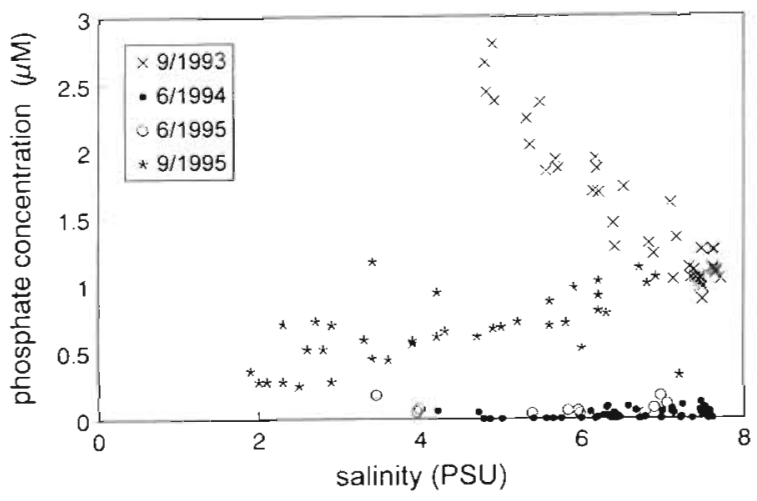

Fig. 2. Phosphate concentrations along salinity gradients between the mouth of the Szwina and the open Pomeranian Bight

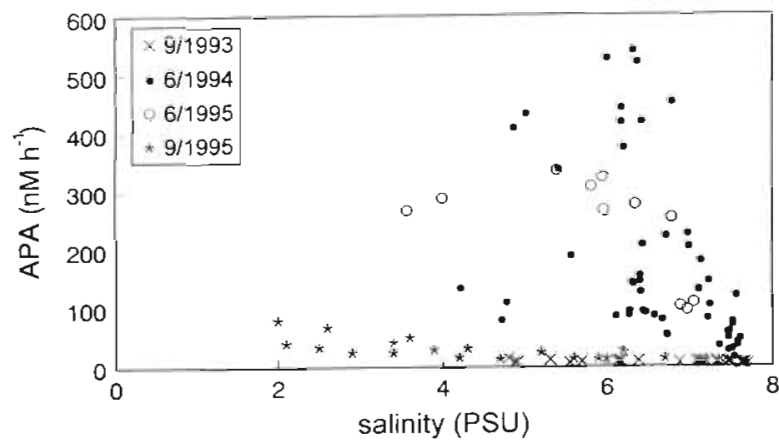

Fig. 3. Alkaline phosphatase activities (APA) along salinity gradients between the mouth of the Szwina and the open Pomeranian Bight 


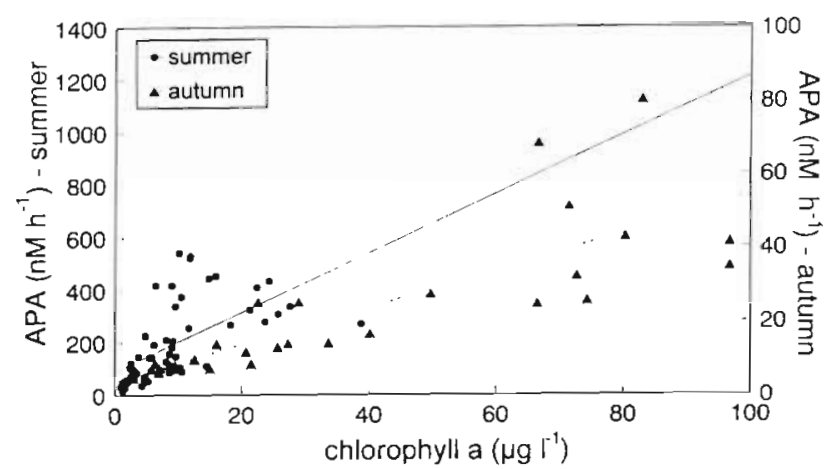

Fig. 4. Relationship between APA and chlorophyll a along salinity gradients in summer and in autumn. Correlation coefficients between these 2 parameters in summer of 1994 and 1995: $\mathrm{r}=0.59, \mathrm{n}=56, \mathrm{p}=0.01$; and in autumn 1993 and 1995:

$$
r=0.82, n=32, p=0.01
$$

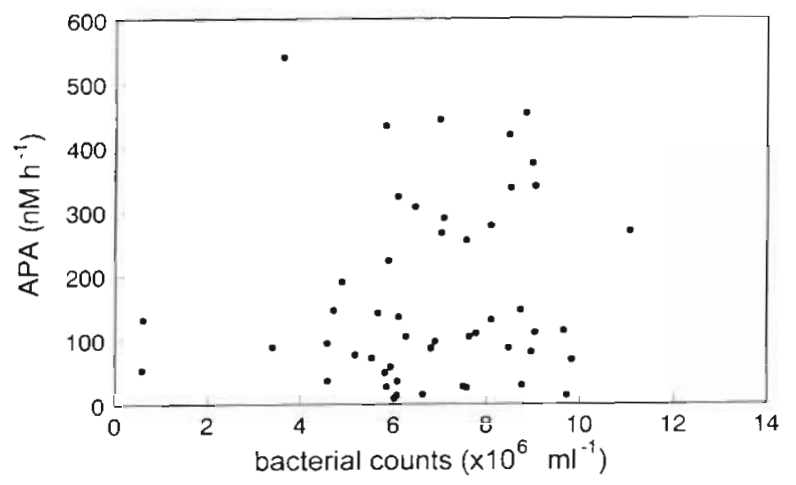

Fig. 5. Relationship between APA and bacterial counts in all investigation periods

The concentration of chl $a$, like many other measured parameters (POC, community respiration; Pollehne et al. 1995, Jost \& Pollehne 1998), decreased along the salinity gradient between 2 and 8 PSU and was well correlated with the decrease of APA. (Fig. 4).

Table 1. APA, phosphate concentration, and phytoplankton and bacterial biomass at the beginning and at the end of mesocosm experiments

\begin{tabular}{|c|c|c|c|c|}
\hline & \multicolumn{2}{|c|}{$\begin{array}{l}\text { Outflowing lagoon } \\
\text { water (Tank 1) }\end{array}$} & \multicolumn{2}{|c|}{$\begin{array}{l}\text { Arkona Basin } \\
\text { water (Tank 2) }\end{array}$} \\
\hline & Start & End & Start & End \\
\hline Salinity (PSU) & \multicolumn{2}{|c|}{4.4} & \multicolumn{2}{|c|}{7.6} \\
\hline $\mathrm{PO}_{4}^{3-}(\mu \mathrm{M})$ & 2.54 & 0.06 & 0.5 & 0.07 \\
\hline $\operatorname{APA}\left(\mathrm{nM} \mathrm{h}^{-1}\right)$ & 7.7 & 147.2 & 3.7 & 8.4 \\
\hline 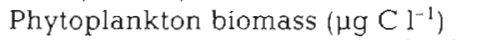 & 120 & 3950 & 160 & 310 \\
\hline Spec. phytopl APA (nmol $\left.\mu g^{-1} h^{-1}\right)$ & 3 & 3.3 & 1.1 & 1.3 \\
\hline Bacterial counts $\left(\times 10^{9} \mathrm{l}^{-1}\right)$ & 3 & 10 & 2 & 3 \\
\hline Spec. bacterial APA (nmol cell ${ }^{-1} \mathrm{~h}^{-1}$ ) & 7 & 14 & 2 & 3 \\
\hline Bacterial biomass $\left(\mu g \mathrm{Cl}^{-1}\right)$ & 40.6 & 128.6 & 19.4 & 29.4 \\
\hline
\end{tabular}

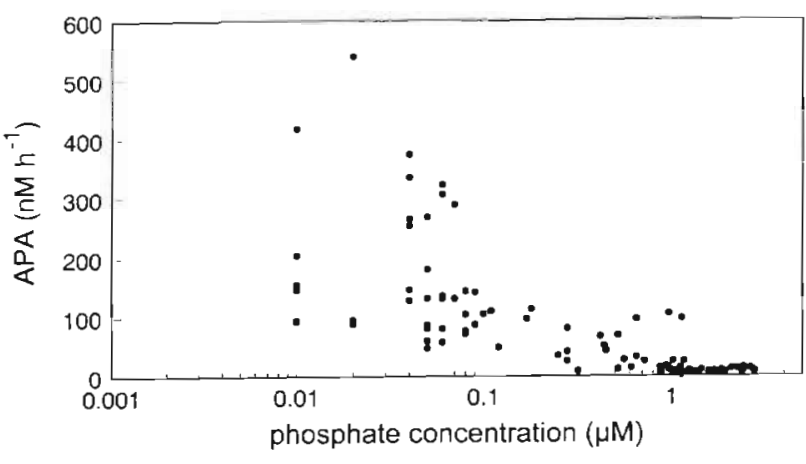

Fig. 6. Relationship between APA and phosphate concentrations in all investigation periods. Correlation coefficient between APA and phosphate concentrations of $<1 \mu \mathrm{M}: r=-0.52$, $\mathrm{n}=63, \mathrm{p}=0.01$

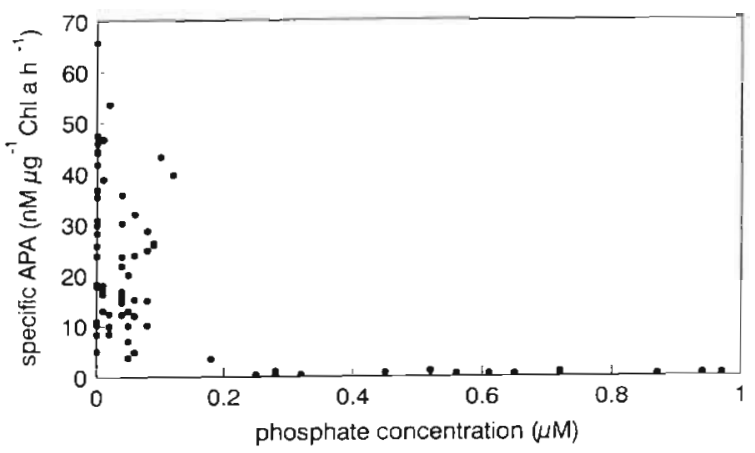

Fig. 7. Specific APA at phosphate concentration of $<1 \mu \mathrm{M}$, the range in which regulatory function of phosphate on APA took place

In contrast to this, APA did not correlate with bacterial counts or biomass values (Fig. 5).

An inverse relationship between APA and phosphate concentrations was always observed when the latter were below $1 \mu \mathrm{M}$ (Fig. 6). At concentrations of $>1 \mu \mathrm{M}$, there was no relationship between these 2 parameters. Therefore, we were able to define a threshold phosphate concentration of $1 \mu \mathrm{M}$ for the regulatory function of phosphate on APA. At phosphate concentrations of $<0.2 \mu \mathrm{M}$, very short hydrolysis times of substrates of APA (median value $6 \mathrm{~h}$ ) were found. They increased to $25 \mathrm{~h}$ at phosphate concentrations of between 0.2 and $1 \mu \mathrm{M}$ and to $119 \mathrm{~h}$ at concentrations of $>1 \mu \mathrm{M}$.

At phosphate concentrations of up to $1 \mu \mathrm{M}$, the range at which regulation took place, the quotient APA/chl a (termed specific APA) was calculated. At normal autumnal phosphate concentrations $(0.28$ 
to $2.66 \mu \mathrm{M}$ ), the specific APA values ranged

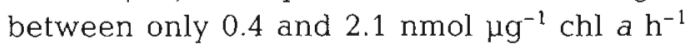
due to the higher phosphate input. At phosphate concentrations of $<0.2 \mu \mathrm{M}$, characteristic for the summer situation, much higher values of specific APA (4.7 to $65.5 \mathrm{nmol} \mathrm{\mu g}^{-1} \mathrm{chl} \mathrm{a}$ $\mathrm{h}^{-1}$ ) were calculated (Fig. 7).

As for the drift investigations, an inverse relationship between phosphate and APA could be detected in the mesocosm experiments. The development of APA during decreasing phosphate concentrations, as a result of phytoplankton growth, was observed in outflowing lagoon water (Tank 1). The increase in APA was more related to the phytoplankton biomass than to the bacterial biomass. Fig. 8a shows the development of APA, phosphate and chl a during the experiment. In Table 1, characteristic parameters at the beginning and end of the experiment are summarized. Intensive growth of phytoplankton led to a 33 times higher biomass and was accompanied by a decrease of inorganic phosphorus from 2.54 to $0.06 \mu \mathrm{M}$. The bacterial biomass was 3 times higher. The APA increased from 7.7 to $147 \mathrm{nM} \mathrm{h}^{-1}$.

In addition, we performed this experiment with water from the open Baltic Sea (Arkona Basin, Tank 2) which has a different nutrient background. The same relationship between APA and phosphate was observed, however the quantitative level was different (Fig. 8b, Table 1). High values of APA were also measured in this experiment when phosphate concentrations fell below $0.3 \mu \mathrm{M}$.

Depending on the available amounts of nutrients, chlorophyll concentrations increased much more strongly in Tank 1 than in Tank 2. The specific APA remained on the same level during the incubation time (Table 1). It was higher in the outflowing lagoon water than in the water from the open Baltic Sea.

As found in drift experiments, no interaction between APA and phosphate could be seen at phosphate concentrations of $>1 \mu \mathrm{M}$.

\section{DISCUSSION}

Inverse relationships between APA and phosphate have been shown for phytoplankton communities (Cembella et al. 1984, Chróst \& Overbeck 1987, Jansson et al. 1988), bacteria (Hassan \& Pratt 1977, Chróst \& Overbeck 1990, Ammerman 1991), and algal cultures (Kuenzler \& Perras 1965, Cembella et al. 1984, Mahasneh et al. 1990, Hernandez et al. 1993). Paasche \& Erga (1988) and Chróst (1991) found that these rela-
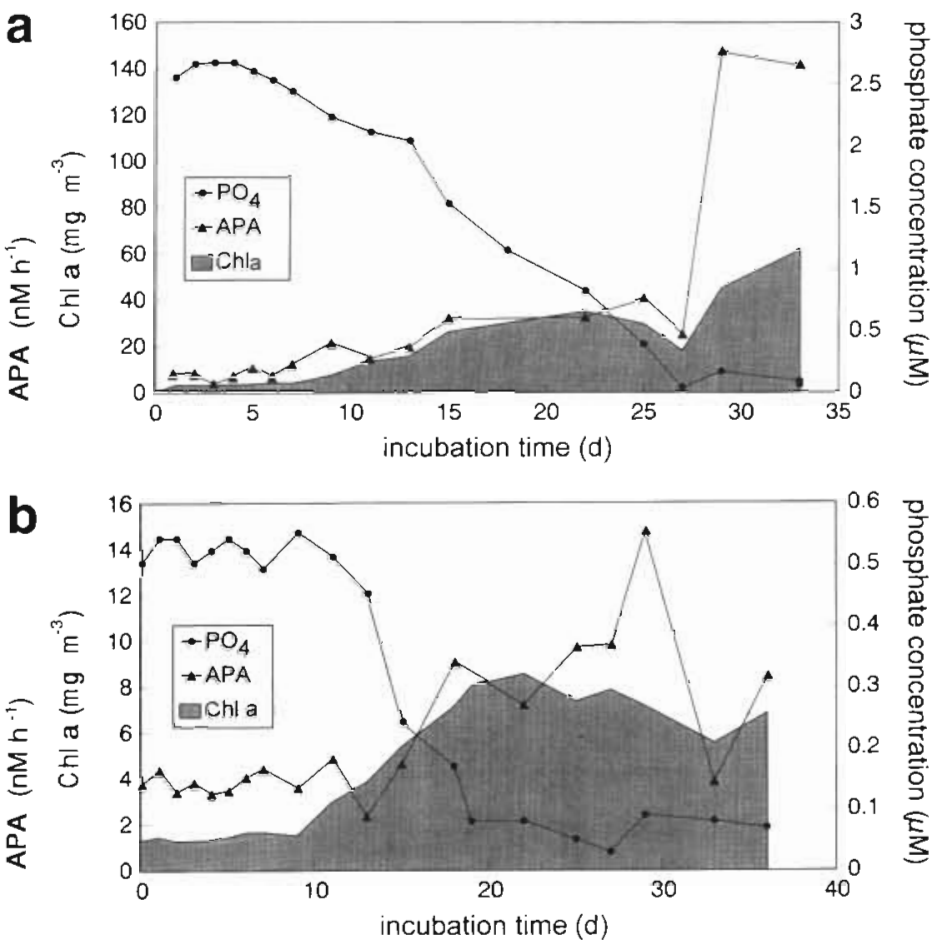

Fig. 8. Phosphate concentrations, chlorophyll $a$, and APA in mesocosm experiments. (a) Outflowing lagoon water (Tank 1). (b) Arkona Basin water (Tank 2)

tionships are restricted to concentrations below a certain level of phosphate; however, a threshold was not defined clearly. Depending on the physico-chemical characteristics, the threshold level for this regulatory function is variable from ecosystem to ecosystem (Healy \& Herndl 1980, Chróst \& Overbeck 1987, Davis \& Smith 1988, Chróst 1991).

The Pomeranian Bight is characterized by a pronounced seasonality in phosphate concentrations. The organic phosphorous content (particulate and dissolved) shows an inverse annual course. It increases from 0.3 to $0.4 \mu \mathrm{M}$ in winter and up to 1.3 to $1.4 \mu \mathrm{M}$ during the growth season (Nehring pers. comm.). The percentage of organic phosphorus encompasses 20 to $24 \%$ of total phosphorus in winter and 90 to $98 \%$ in the growth season (May to October). In the outflowing lagoon water, the organic phosphorus is higher, up to 3.8 $\mu \mathrm{M}$. The plankton community reacts to the exhausted phosphate pool in summer, with increased activity of alkaline phosphatase to tap into organic phosphorus sources for primary and bacterial production. This mechanism seems to be efficient because parallel investigations have shown that phytoplankton does not show any decrease in specific production (Jost \& Pollehne 1998). When phosphate concentrations are at the detection limit in summer and hydrolysis rates are about 10 to $30 \% \mathrm{~h}^{-1}$, the organic phosphorous pool 
will be converted within 3 to $10 \mathrm{~h}$. Under hydrochemical conditions in autumn, an organic phosphorous content of about $0.9 \mu \mathrm{M}$, and median hydrolysis rates of about $1 \% \mathrm{~h}^{-1}$, the phosphorous turnover needs about $100 \mathrm{~h}$

A threshold of $1 \mu \mathrm{M}$ phosphate could be defined for the regulatory function of phosphate on APA. Two different mechanisms seem to be responsible for the interaction between APA and phosphate at concentrations of $<1 \mu \mathrm{M}$. Very low phosphate concentrations in summer $(<0.2 \mu \mathrm{M})$ caused a stimulation of production of alkaline phosphatase enzyme in algal cells and bacterial cells leading to very high specific APA levels. At phosphate concentrations of between 0.2 and $1.0 \mu \mathrm{M}$, APA and chl a were linearly related and specific APA remained at the same level. In this case, which was found in autumn and in the mesocosm experiments, APA in the water column is simply a function of biomass. When APA was set in relation to bacterial numbers, the APA per bacterial cell also showed an increasing tendency towards lower phosphate concentrations. Below $0.2 \mu \mathrm{M}$ phosphate, $0.03 \pm 0.02 \mathrm{fmol}$ cell $^{-1} \mathrm{~h}^{-1}(\mathrm{n}=39)$ was detected; at phosphate concentrations of $>0.2 \mu \mathrm{M}$ only $0.005 \pm 0.004 \mathrm{fmol} \mathrm{cell}^{-1} \mathrm{~h}^{-1}$ $(\mathrm{n}=11)$ was estimated. At phosphate concentrations of $>1 \mu \mathrm{M}$, there was no stimulation of APA by phosphate. This situation prevailed in the autumn of 1993.

The APA in our investigations resulted from algae and bacteria; the values include soluble and cell bound APA. In field investigations it is not possible to separate algal and bacterial APA clearly. Size fractionation by filtration provides only limited information, because alkaline phosphatase will be released from algae (Chróst 1991). The largest portion of bacterial alkaline phosphatase is cell-surface bound, but is shed easily under low stress conditions (Chróst 1991, Martinez \& Azam 1993). Therefore, APA of both groups of organism can be found in the soluble fraction. On the other hand, in the Pomeranian Bight, between 7 and $55 \%$ of bacterial production was particle-associated (Jost \& Pollehne 1998). Therefore, algal and bacterial APA cannot be distinguished by size fractionation. However, there are some indications that algal APA dominated the bacterial APA as follows: (1) phytoplankton accounted for up to $64 \%$ of the particulate organic carbon (Pollehne et al. 1994); (2) in the salinity gradient, APA correlated well with chl a but not with bacterial numbers or biomass - this is in contrast to glucosidase and peptidase activities, which correlated well with bacterial counts (Nausch et al. 1998); (3) phytoplankton biomass was higher than the bacterial biomass by a factor of 3 to 6 . The lower factors were found in the outflowing lagoon water and the higher ones after dilution in the open bigh.t.
The mesocosm experiments support our results from the drift experiments. The increase in APA can be attributed more to phytoplankton biomass than to bacteria. In contrast to drift experiments, the specific phytoplankton APA remained at the same level, which can be related to different initial nutrient conditions. In the mesocosm experiments we started from a high nutrient level (winter situation). In summer, as in the drift experiments, inorganic phosphate concentrations remained low over a long period (months). Therefore, phytoplankton may be more sensitive to phosphate deficiency in summer and may react with stimulation of alkaline phosphatase synthesis. The experiment with Arkona Basin water demonstrates that the interaction between APA and phosphate also functions under different hydrographical and biological conditions. Depending on the community composition and its adaption to the hydrographical conditions, the reactions have different quantitative levels. In the outflowing lagoon water (Tank 1), the limnic species Diatoma elongatum and Skeletonema subsalsum developed, whereas in the Arkona Basin water Skeletonema costatum, an indicator for higher salinity, occurred (Wasmund et al. 1998).

A shift from limnic species in the outflowing lagoon water to brackish water species after mixing with water from the open bight was also observed during the drift experiments (Pollehne et al. 1995, Jost \& Pollehne 1998). The decrease of APA along the salinity gradient may be influenced by the decrease of phytoplankton biomass rather than by the species composition. The specific phytoplankton APA is not different in the outflowing lagoon water and after dilution. The specific APA is mainly influenced by the phosphate concentration.

Acknowledgements. This work was supported by the Bundesministerium für Bildung. Wissenschaft, Forschung und Technologie (BMBF) through grant 03F0165B. I am grateful to Dr F. Pollehne, Dr G. Jost, Dr M. Voss and Dr N. Wasmund for their cooperation during the cruises and for bacterial production and bacterial counts, POC, PON and chlorophyll a data. I also thank Doris Setzkorn and Annett Grüttmüller for technical assistance

\section{LITERATURE CITED}

Ammerman JW (1991) Role of ecto-phosphorylases in phosphorus regeneration in estuarine and coastal ecosystems. In: Chróst RJ (ed) Microbial enzymes in aquatic environments, Springer-Verlag, New York, p 165-186

Ammerman JW, Azam F (1991) Bacterial 5'-nucleotidase in estuarine and coastal marine waters: role in phosphorus regeneration. Limnol Oceanogr 36:1437-1446

Cembella AD, Anita NJ, Harrison PJ (1984) The utilization of inorganic and organic phosphorous compounds as nutrients by eukaryotic microalgae: a multidisciplinary perspective: part 2. Crit Rev Microbiol 11:13-81 
Chróst RJ (1991) Environmental control of the synthesis and activity of aquatic microbial ectoenzymes. In: Chróst RJ (ed) Microbial enzymes in aquatic environments. Springer-Verlag, New York, p 29-59

Chróst RJ, Overbeck J (1987) Kinetics of alkaline phosphatase activity and phosphorus availability for phytoplankton and bacterioplankton in Lake Plußsee (north German eutrophic lake. Microb Ecol 13:229-248

Chróst RJ, Overbeck J (1990) Substrate-ectoenzyme interaction: significance of $\beta$-glucosidase activity for glucose metabolism by aquatic bacteria. Arch Hydrobiol Beih Ergeb Limnol 34:93-98

Coleman AW (1980) The use of DAPI for identifying and counting aquatic microflora. Limnol Oceanogr 25:943-948

Davis AG, Smith MA (1988) Alkaline phosphatase activity in the Western English Channel. J Mar Biol Assoc UK 68: $239-250$

Frankowski L, Bolałek J (1997) Phosphate desorption from sediments in the Pomeranian Bay (Southern Baltic). Oceanol Stud 1:205-214

Fry JC (1988) Determination of biomass. In: Austin B (ed) Methods in aquatic bacteriology. John Wiley and Sons, Chichester, p $27-67$

Grasshoff K, Ehrhardt M, Kremling K (eds) (1983) Methods of seawater analysis, 2nd edn. Verlag Chemie, Weinheim

Gulati RD, Martinez CP, Siewertsen K (1995) Zooplankton as a compound mineralising and synthesizing system: phosphorus excretion. Hydrobiologia 315:25-37

Hantke B, Fleischer P, Domany I, Koch M, Pless P, Wiendl M, Melzer A (1996) P-release from DOP by phosphatase activity in comparison to $\mathrm{P}$ excretion by zooplankton. Studies in hardwater lakes of different trophic level. Hydrobiologia 317:151-162

Hassan HM, Pratt D (1977) Biochemical and physiological properties of alkaline phosphatases in five isolates of marine bacteria. J Bact Mar 129:1607-1612

Healy FP, Herndl LL (1980) Physiological indicators of nutrient deficiency in lake phytoplankton. Can J Fish Aquat Sci $37: 442-453$

HELCOM (1996) Third periodic assesment of the state of the marine environment of the Baltic Sea, 1989-93. Baltic Sea Environ Proc 64B: 89-100

Hernandez I, Fernandez JA, Niell FX (1993) Influence of phosphorus status on the seasonal variation of alkaline phosphatase activity in Pophyra umbilicalis (L.) Kützing. J Exp Mar Biol Ecol 173:182-196

Hoppe HG (1983) Significance of exoenzymatic activities in the ecology of brackish water: measurements by means of methylumbelliferyl-substrates. Mar Ecol Prog Ser 11: 299-308

Hoppe HG (1993) Use of fluorogenic model substrates for extracellular enzyme activity (EEA) measurement of bacteria. In: Kemp PF, Sherr BF, Sherr EB, Cole JJ (eds) Handbook of methods in aquatic microbial ecology. Lewis Publishers, Boca Raton, p 423-431

Jansson M, Olsson H, Pettersson K (1988) Phosphatases: origin, characteristics and functioning in lakes. Hydrobiologia 170:157-175

Jost $G$, Pollehne F (1998) Coupling of autotrophic and heterotrophic processes in a Baltic estuarine mixing gradient (Pomeranian Bight). Hydrobiologia 363:107-115

Kepner RL, Pratt JR (1994) Use of fluorochromes for direct enumeration of total bacteria in environmental samples: past and present. Microb Rev 58:603-615

Kerstan E, Nausch M (1998) Chemical and biological interactions in mixing gradients in the Pomeranian Bight (Southern Baltic). ICES Coop Res Rep (in press)
Kuenzler EJ, Perras JP (1965) Phosphatases of marine algae. Biol Bull 128:271-284

Lapointe BE (1995) A comparison of nutrient-limited productivity in Sargassum natans from neritic vs. oceanic waters of the Western North Atlantic. Limnol Oceanogr 40: $625-633$

Mahasneh IA, Graninger SLJ, Whitton BA (1990) Influence of salinity on hair formation and phosphatase activities of the blue-green algae (cyanobacterium) Calothrix virguieri D253. Br Phycol J 25:25-32

Martinez J, Azam F (1993) Periplasmatic aminopeptidase and alkaline phosphatase activities in a marine bacterium implications for substrate processing in the sea. Mar Ecol Prog Ser 92:89-97

Moegenburg SM, Vanni MJ (1991) Nutrient regeneration by zooplankton: effects on nutrient limitation of phytoplankton in a eutrophic lake. J Plankton Res 13:573-588

Nagata T, Kirchman DL (1992) Release of dissolved organic matter by heterotrophic protozoa: implications for microbial food web. In: Reynolds CS, Watanabe X (eds) Vertical structure in aquatic environments and its impact on trophic linkages and nutrient fluxes. Arch Hydrobiol Beih Ergeb Limnol 35:99-109

Nausch G, Nehring D, Aertebjerg G (1998) Anthropogenic nutrient load of the Baltic Sea. Limnologica (in press)

Nehring D, Matthäus W, Lass HU, Nausch G, Nagel K (1995) The Baltic Sea in 1995 - beginning of a new stagnation period in its central deep waters and decreasing nutrient load in its surface layer. Dtsch Hydrogr Z 47 319-327

Paasche E, Erga SR (1988) Phosphorus and nitrogen limitation of phytoplankton in the inner Oslofjord (Norway). Sarsia 73:229-243

Pastuszak M, Nagel K, Nausch G (1996) Variability in nutrient distribution in the Popmeranian Bay in September 1993. Oceanologia 38:195-225

Pollehne $F_{1}$ Busch $S$, Jost $G$, Meyer-Harms B, Nausch M, Reckermann $M$, Schäning $P$, Setzkorn $D$, Wasmund $N$ (1994) Primärproduktion, Abgabe gelöster Substanzen und deren Aufbereitung durch Bakterien und Protozoen In: von Bodungen $B$ (ed) Transport- und Umsatzprozesse in der Pommerschen Bucht-einem anthropogen belasteten Übergangsgebiet zwischen Küste und offener Ostsee. 1. Zwischenbericht 1994, Rostock-Warnemünde, p 95-126

Pollehne F, Busch S, Jost G, Meyer-Harms B, Nausch M, Reckermann $M$, Schäning $P$, Setzkorn $D$, Wasmund $N$ Witek Z (1995) Primary production patterns and heterotrophic use of organic material in the Pomeranian Bay (Southern Baltic). Bull Sea Fish Inst 3:43-60

Postel L, Hernandez-Leon S, Gomez M, Torres S, Mikkat U, Portillo-Hahnefeld A (1992) Zooplankton oxygen consumption and nutrient release in relation to species composition, animal size and environmental conditions in the Baltic Sea during May and August. ICES CM 1992/L:21

Rohde KH, Nehring D (1979) Ausgewählte Methoden zur Bestimmung von Inhaltsstoffen im Meer- und Brackwasser. Geod Geoph Veröff R IV 27:1-68

Tamminen $T$ (1989) Dissolved organic phosphorus regeneration by bacterioplankton: 5 -nucleotidase activity and subsequent phosphate uptake in a mesocosm enriched experiment. Mar Ecol Prog Ser 58:89-100

UNESCO (1994) Protocols for the Joint Global Ocean Flux Study (JGOFS) core measurements. IOC/SCOR Manual and Guides 29:128-134

Vadstein O, Brekke O, Andersen T, OIsen Y (1995) Estimation of phosphorus release rates from natural zooplankton 
communities feeding on planktonic algae and bacteria Limnol Oceanogr 40:250-262

von Bodungen B, Graeve M, Kube J, Lass U, Meyer-Harms B,

Mumm N, Nagel K, Pollehne F, Powilleit M, Reckermann M, Sattler C, Siegel H, Wodarg D (1995) Stoff-Flüsse am Grenzfluß: Transport- und Umsatz-Prozesse im Über-

Editorial responsibility: Frede Thingstad,

Bergen, Norway gangsbereich zwischen Oderästuar und Pommerscher Bucht (TRUMP). Geowiss 13:479-485

Wasmund N, Nausch G, Matthäus W (1998) Phytoplankton spring blooms in the southern Baltic Sea - spatio-temporal development and long-term trends. J Plankton Res 20:1099-1117

Submitted: September 12, 1997; Accepted: May 15, 1998

Proofs received from author(s): September 30, 1998 